\title{
New data to the vascular flora of the central Pamir Alai Mountains (Tajikistan, Central Asia). Part II.
}

Marcin Nobis \& Arkadiusz Nowak

New data to the vascular flora of the central Pamir Alai Mountains (Tajikistan, Central Asia). Part II. - Čas. Slez. Muz. Opava (A), 60: 259-262, 2011.

Abstract. The paper presents the distributional data of three species: Amaranthus deflexus L., Euphorbia maculata L., Rubus praecox Bertol. s. 1., new to the flora of the central Pamir Alai Mts in Tajikistan. A list of localities of the species in the Tajik Pamir Alai Mts and habitat preferences are presented. Their distribution is mapped and illustrations of the species are provided.

Key words: new records, vascular plants, Pamir Alai Mts, Tajikistan

\section{Introduction}

Tajikistan is a country located almost entirely in the central part of the Pamir Alai mountains system lying on the border of the subtropical and temperate zones. It is situated in Central Asia between $36^{\circ} 40^{\prime}-41^{\circ} 05^{\prime} \mathrm{E}$ and $67^{\circ} 31^{\prime}-75^{\circ} 14^{\prime} \mathrm{N}$ (Fig. 1). Tajikistan is also one of the regions richest in plant species diversity in the former Soviet Union. According to the tenvolume study of the flora of the former Soviet Socialist Republic of Tajikistan, completed by a multi-author team: (Ovchinnikov 1957, 1963, 1968, 1978; Ovchinnikov \& Koczkareva 1975; Ovchinnikov \& Kinzikaeva 1981; Chukavina 1984; Kochkareva 1986; Kinzikaeva 1988; Rasulova 1991) and supplemented by the works of other researchers (e.g., Zakirov 1961; Ikonnikov 1983), ca 4550 vascular plant species are known from the country. This number is not final as recently some new species have been described from Tajikistan (e.g., Fritsch et al. 2002; Khassanov et al. 2007; Fritsch \& Friesen 2009; Ranjbar et al. 2010; Nobis 2011b) and new records to its flora have been published (e.g., Lazkov 2008; Nobis et al. 2010, 2011; Nobis 2011a, Nobis \& Nowak 2011). According to literature data, ca $30 \%$ of the entire flora of vascular plants known from Tajikistan are generally accepted endemics of the country (endemics s.str. + subendemics) (Rassulova 1991; Nowak \& Nobis 2010; Nowak et al. 2011).

During our exploration of the Pamir Alai Mts in Tajikistan we found many species that are very rare in the flora of the country. Some were never reported form Tajikistan. In this paper, three vascular plant species being new to the flora of Tajikistan are presented.

\section{Material and methods}

Specimens were collected in 2007, 2009 and 2011 at different localities in Tajikistan in several geobotanical regions (Goncharov 1937). Herbarium materials of the newly discovered species were revised in the herbaria LE, TAD, FRU for comparative purposes (specimens from the species' ranges) and to supplement their distribution in Tajikistan when relevant. The distribution of the species examined in Tajikistan is mapped in Fig. 1. Specimens of taxa listed below and collected by us, are deposited in the herbaria KRA and OPUN.

\section{LIST OF SPECIES}

\section{Amaranthus deflexus L. (Amaranthaceae)}

GENERAL DISTRIBUTION: Widely distributed species, native in South and North America, introdused in Europe (central and southern part), Africa, Asia (form Turkish up to Pakistan).

OCCURRENCE IN TAJIKISTAN: Amaranthus deflexus is an alien species in the flora of Tajikistan: a neophyte (kenophyte, epecophyte). The species occurs in anthropogenic habitats (mostly on roadsides).

SPECIMENS SEEN: South Tajikistanian region: Dushanbe, Rudaki St., between flagstones (5 July 2009, leg. M. Nobis). 


\section{Euphorbia maculata L. (Euphorbiaceae)}

Syn: Tithymalus maculatus (L.) Moench., Chamaesyce maculata (L.) Small., Anisophyllum maculatum (L.) Haw., Xamesike maculata (L.) Raf.

GENERAL Distribution: The species is native to North and South America, introduced in Europe (central and southern) and Asia (Caucasus, Iran, China, Taiwan).

OCCURRENCE IN TAJIKISTAN: Euphorbia maculata is an alien species in the flora of Tajikistan: a neophyte (kenophyte, epecophyte). The species occurs in anthropogenic habitats, mostly on roadsides.

SPECIMENS SEEN: South Tajikistanian region: Dushanbe, Aini St., between flagstones (20 June 2011, leg. M. Nobis \& A. Nowak).

\section{Rubus praecox Bertol. s. I. (Rosaceae)}

Syn: Rubus procerus P.J. Müll.

GENERAL DISTRIBUTION: Rubus praecox is spread within Mediterranean and Irano-Turanian regions from the Iberian peninsula in the west up to Middle and Central Asia in the east. The species is also scattered in southern part of Central Europe.

OCCURRENCE IN TAJIKISTAN: Rubus praecox is a species with uncertain status in Tajik's flora, likely to be an antropophyte. However it could be also a native species, despite the plant occurs mainly in man-made habitats. Further chorological and ecological researches are needed to clear this vagueness. The species have been observed in anthropogenic habitats, mostly on road verges, along fences, railways and walls. Rubus praecox was earlier mentioned as a rare species only from Dushanbe (Nowak et al. 2008). Further researches confirm, that the species is more frequent in Tajikistan and the species is supposed to occur commonly in Tajikistan as well as in neighbouring countries.

SPECIMENS SEEN: South Tajikistanian region: Dushanbe, in many places, especially in city outskirts (June - July 2007 - 2011, not. and leg. M. Nobis \& A. Nowak); Hissar region: Takob, on road verges (July 2009, leg. M. Nobis and A. Nowak); near Varzob, on road verges (June 2010, not. and leg. M. Nobis \& A. Nowak); Zeravshan region: Sudzhina, on road verges (July 2009, leg. M. Nobis \& A. Nowak).

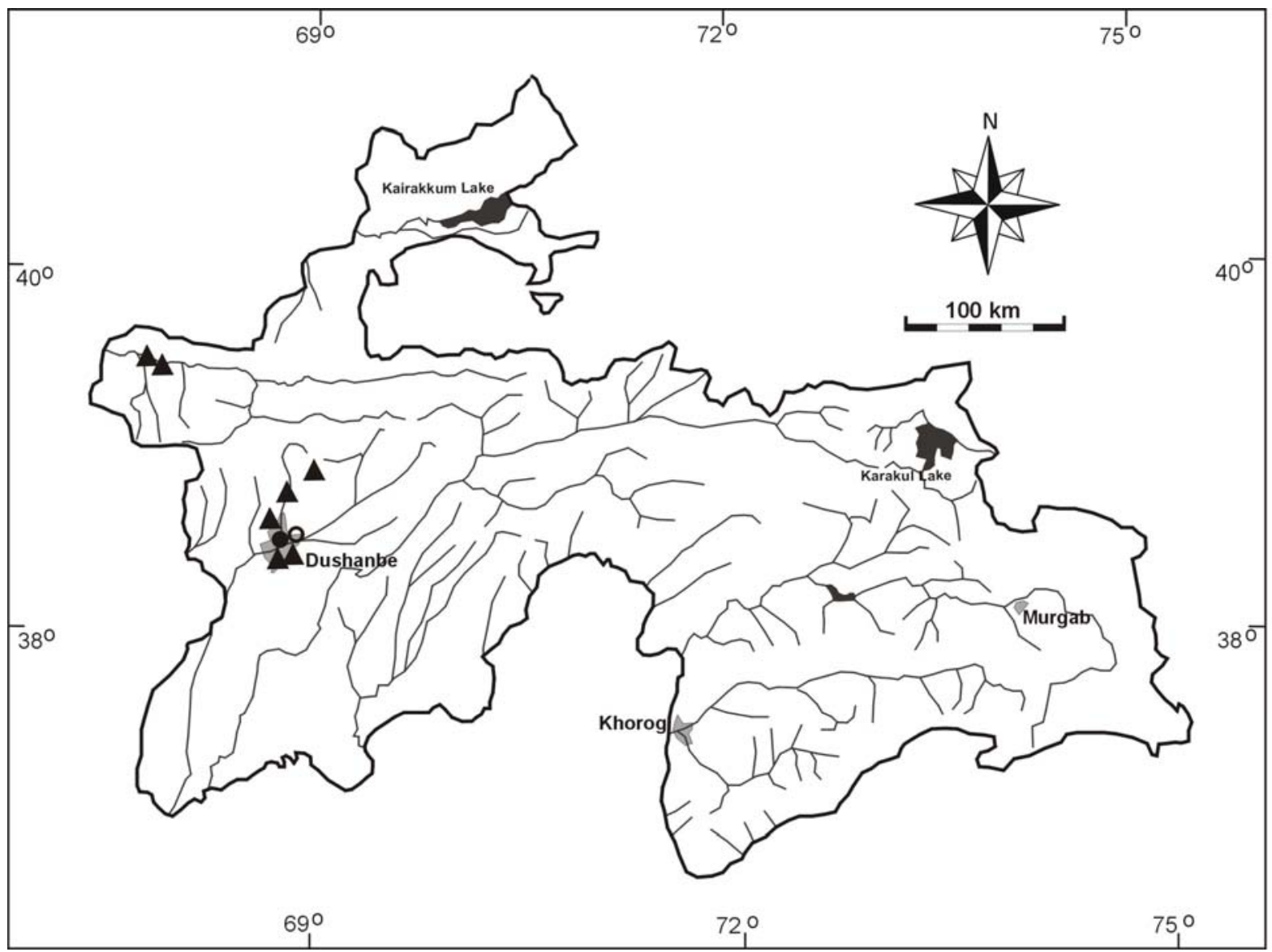

Fig. 1: Distribution map of species new to the flora of Tajikistan: • - Amaranthus deflexus L.; $\circ-$ Euphorbia maculata L.; $\mathbf{\Delta}-$ Rubus praecox Bertol. s. 1 . 

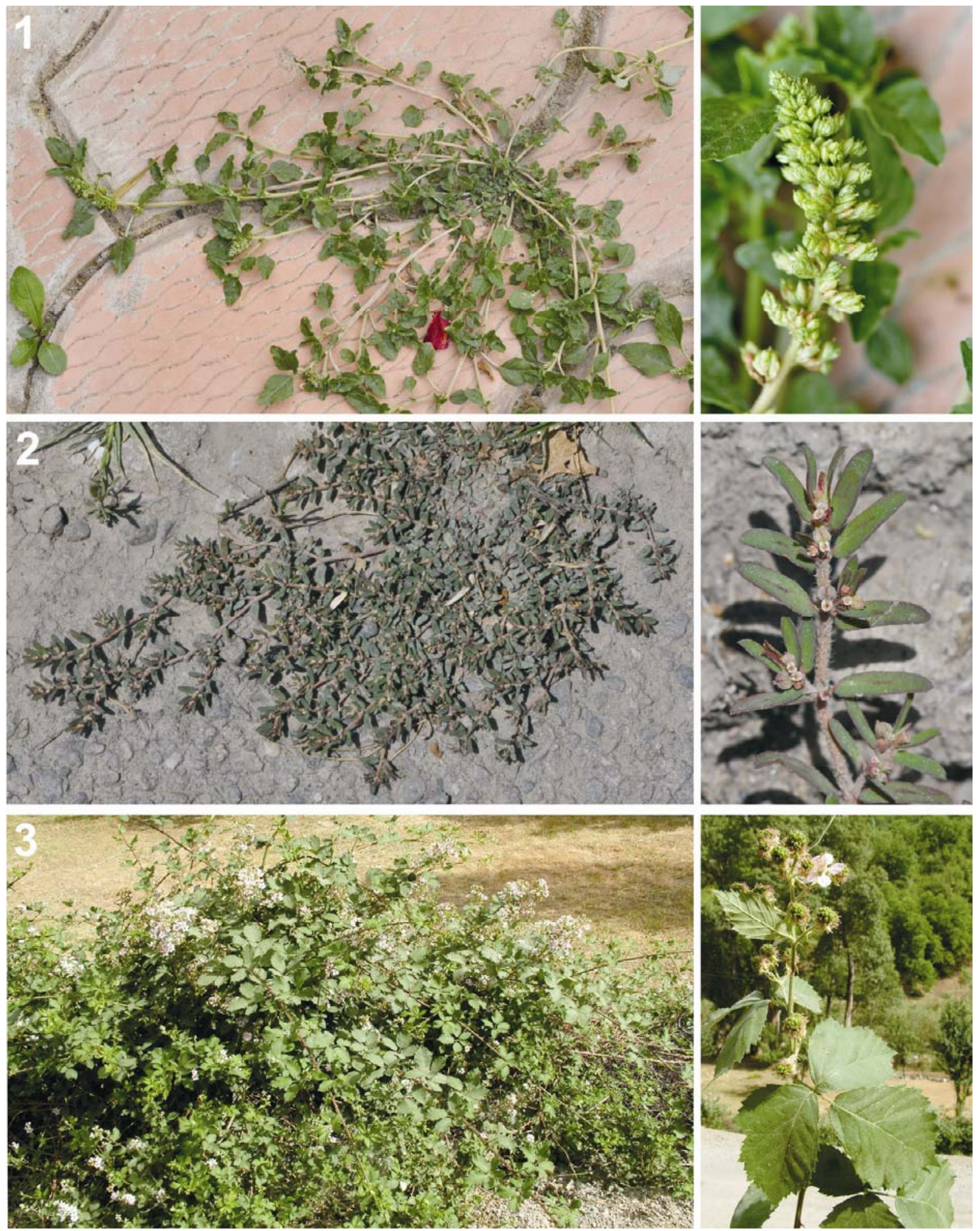

Fig. 2: General habit of new species to the flora of Tajikistan: 1 - Amaranthus deflexus L.; 2 - Euphorbia maculata L.; 3 - Rubus praecox Bertol. s. lato.

\section{References}

Chukavina A. P. ed. (1984): Flora Tadzhikskoi SSR. 7. Zontichnye - Verbenovye. - Izdatel'stvo Nauka, Leningrad (in Russian).

Fritsch R. M. \& Friesen N. (2009): Allium oreotadzhikorum and Allium vallivanchense, two new species of Allium subg. Polyprason (Alliaceae) from the Central Asian republic Tajikistan. - Feddes Repert., 120(3-4): 221-231. 
Fritsch R. M., Khassanov F. O. \& Matin F. (2002): New Allium taxa from Middle Asia and Iran. Stapfia, 80: 381-393.

Goncharov N. F. (1937): Raiony flory Tadshikistana i ikh rastitelnost. Flora Tadzhykistana. 5. Izdatelstvo Akademii Nauk SSSR, Moskwa - Leningrad (in Russian).

Ikonnikov S. S. (1983): Notulae ad floram Pamir \& Badachschan. - Novosti Sist. Vyssh. Rast., 20: 187-195 (in Russian).

Khassanov F. O., Shomuradov H. \& Tobaev K. (2007): A new Allium L. species from Middle Asia. Linzer Biol. Beitr., 39(2): 799-802.

Kinzikaeva G. K. ed. (1988): Flora Tadzhikskoi SSR. 9. Marenovye - Slozhnotsvetnye. Izdatelstvo Nauka, Leningrad (in Russian).

Kochkareva T. F. ed. (1986): Flora Tadzhikskoi SSR. 8. Kermekovye - Podorozhnikovye. Izdatelstvo Nauka, Leningrad (in Russian).

Lazkov G. (2008): Gastrolychnis alexeenkoi Lazkov (Caryophyllaceae) - a new species to the flora of Tajikistan. - Novisti Sist. Vyssh. Rast., 40: 68-69 (in Russian with English summary).

Nobis M. (2011a): Remarks on the taxonomy and nomenclature of the Stipa tianschanica complex (Poaceae), on the base of a new record for the flora of Tajikistan (central Asia). - Nord. J. Bot., 29: 194-199.

- (2011b): Stipa ×brozhiana (Poaceae): a new hybrid taxon from the western Pamir Alai Mts (Middle Asia) and taxonomical notes on Stipa $\times$ tzvelevii. - Nord. J. Bot., 29: 458-464.

Nobis M., Kowalczyk T. \& Nowak A. (2011): Eleusine indica (Poaceae): a new alien species in the flora of Tajikistan. - Polish Bot. J., 56(1): 121-123.

Nobis M. \& Nowak A. (2011): New data on the vascular flora of the Central Pamir Alai Mountains (Tajikistan, Central Asia). - Polish Bot. J., 56(2): 195-201.

Nobis M., Nowak A. \& Zalewska-Gałosz J. (2010): Potamogeton pusillus agg. in Tajikistan (Middle Asia). - Acta Soc. Bot. Poloniae, 79(3): 235-238.

Nowak A., Kozak M., Nobis M. \& Kusza G. (2008): Atlas of the vascular flora of Tajikistan. Part I. Stow. Ochr. Przyrody BIOS, Opole.

Nowak A. \& Nobis M. (2010): Tentative list of endemic vascular plants of Zeravshan Mts in Tajikistan (Middle Asia): distribution, habitat preferences and conservation status of species. - Biodiv. Res. Conserv., 19: 65-80.

Nowak A., Nowak S. \& Nobis M. (2011): Distribution patterns, ecological characteristic and conservation status of endemic plants of Tadzhikistan - A global hotspot of diversity. - J. Nat. Conserv., 19: 296-305.

Ovczinnikov P. N. ed. (1957): Flora Tadzhikskoi SSR. 1, Paprotnikoobraznye - Zlaki. Izdatelstvo Akademii Nauk SSSR, Moskwa - Leningrad (in Russian).

- ed. (1963): Flora Tadzhikskoi SSR. 2, Osokovye - Orkhidnye. Izdatelstvo Akademii Nauk SSSR, Moskwa Leningrad (in Russian).

- ed. (1968): Flora Tadzhikskoi SSR. 3, Opekhovye - Gvozdichnye. Izdatelstvo Nauka, Leningrad (in Russian).

- ed. (1978): Flora Tadzhikskoi SSR. 5, Krestotsvetne - Bobovye. Izdatelstvo Nauka, Leningrad (in Russian).

Ovczinnikov P. N. \& Kinzikaeva G. K. ed. (1981): Flora Tadzhikskoi SSR. 6, Bobovye (rod Astragal) - Tsinomorievye. Izdatelstvo Nauka, Leningrad (in Russian).

Ovczinnikov P. N. \& Koczkareva T. F. ed. (1975): Flora Tadzhikskoi SSR. 4, Rogolistnikovye Rozotsvetnye. Izdatelstvo Nauka, Leningrad (in Russian).

Ranjbar M., Karamian R. \& Vitek E. (2010): Onobrychis dushanbensis sp. nova endemic to Tajikistan. Nord. J. Bot. 28: 182-185.

Rasulova M. R. ed. (1991): Flora Tadzhikskoi SSR. 10, Slozhnotsvetnye. Izdatelstvo Nauka, Leningrad (in Russian).

Zakirov K. Z. (1961): Flora i rastitelnost basseina reki Zeravshan. 2, konspekt flory. Izdat. Akad. Nauk Uzbek. SSR, Tashkent (in Russian).

Authors' addresses: Marcin Nobis, Department of Plant Taxonomy, Phytogeography and Herbarium, Institute of Botany, Jagiellonian University, Kopernika 27, 31-501 Kraków, Poland; e-mail: m.nobis@uj.edu.pl

Arkadiusz Nowak, Laboratory of Geobotany and Plant Conservation, Department of Biosystematics, Opole University, Oleska 48, 45-022 Opole, Poland; e-mail: anowak@uni.opole.pl 